\title{
Analisis Sideforce Kapal Katamaran Jenis Flat Side Inside dan Simetris Terhadap Performa Maneuvering Kapal dengan Metode CFD
}

\author{
Aryo Tri Septya Nugraha dan I Ketut Aria Pria Utama \\ Departemen Teknik Perkapalan, Fakultas Teknologi Kelautan, Institut Teknologi Sepuluh Nopember (ITS) \\ e-mail: kutama@na.its.ac.id
}

\begin{abstract}
Abstrak-Kapal katamaran memililki berbagai kelebihan dalam aspek hidrodinamika kapal secara teknis. Variasi konfigurasi lambung katamaran asimetris flat side inside dan lambung kapal katamaran simetris memberikan dampak yang berbeda dengan adanya pengaruh sideforce yang ada pada kapal katamaran. Sideforce yang mengenai setiap demihull dapat bersifat menghambat, mengingat adanya induced drag dari kedua demihull yang bersifat menghambat laju kapal. Kapal katamaran yang memiliki perngaruh dari perbandingan jarak melintang kapal dengan panjang kapal (S/L) sehingga dilakukan penelitian untuk $\mathrm{S} / \mathrm{L}=0.2, \mathrm{~S} / \mathrm{L}=0.3$ dan $\mathrm{S} / \mathrm{L}=0.4$. Selain hubungan pengaruh sideforce dengan variasi jenis lambung kapal sideforce juga mampu memberikan pengaruh dalam maneuvering kapal. Dalam proses maneuvering, kapal mengalami kondisi dimana kapal berbelok sehingga penelitian disimulasikan dalam variasi sudut kemiringan, yaitu pada sudut kemiringan $2^{\circ}, 4^{\circ}, 6^{\circ}, 8^{\circ}, 10^{\circ}, 12^{\circ}, 14^{\circ}$ terhadap sumbu Z. Dalam simulasi yang dilakukan dengan metode Computational Fluid Dynamics (CFD) diperoleh nilai sideforce yang selanjutnya diubah menjadi nilai sideforce coefficient (CSF). Selain diperoleh nilai dari sideforce coefficient (CSF) juga diperoleh nilai CT, dimana nilai CSF diperoleh berdasarkan besarnya nilai force pada sumbu y, atau sumbu yang sejajar dengan arah melintang kapal. Sedangkan nilai CT diperoleh berdasarkan nilai besarnya force berdasarkan sumbu $x$, atau sumbu yang sejajar dengan arah memanjang kapal. Perbedaan konfigurasi lambung pada kapal katamaran dapat menyebabkan nilai sideforce dan nilai CSF yang berbeda. Kapal katamaran asimetris flat side inside memiliki nilai sideforce yang lebih besar dibandingkan dengan kapal katamaran simetris. Pada kapal katamaran simetris dan asimetris flat side inside pada sudut kemiringan $2^{\circ}, 4^{\circ}, 6^{\circ}$ nilai CSF lebih kecil daripada nilai CT. Pada sudut kemiringan $8^{o}, 10^{\circ}, 12^{\circ}, 14^{o} \mathrm{CSF}$ memiliki nilai yang lebih besar daripada nilai CT.
\end{abstract}

Kata Kunci-Katamaran, Sideforce, Sideforce Coefficient (CSF), Maneuvering, CFD.

\section{PENDAHULUAN}

$\mathrm{P}$ ENGGUNAAN kapal katamaran sebagai alternatif baru dalam memberikan solusi yang efisien dalam banyak bidang dengan berbagai kelebihan yang dapat di berikan. Tidak hanya kelebihan dalam hal kenyamanan penumpang namun juga kelebihan dalam aspek hidrodinamika kapal secara teknis. Kapal katamaran flat side inside adalah salah satu konfigurasi lambung kapal katamaran dimana pada bagian bridge atau tunnel kapal memiliki bentuk datar. Dengan mengguakan prinsip kapal monohull yang dijadikan katamaran konfigurasi lambung ini memberi keuntungan dengan adanya permukaan area geladak yang lebih luas dibandingakan dengan kapal monohull serta memiliki tingkat stabilitas yang lebih tinggi [1]. Selain kapal katamaran flat side inside adapun katamaran simetris, dimana lambung kapal berbentuk simetris, sehingga dapat memberikan dampak yang signifikan pula untuk performa kapal.

Gelombang memberikan efek yang signifikan pada kapal yang sedang bergerak. Dengan adanya gelombang maka secara langsung mempengaruhi maneuvering kapal, dimana dalam pergerakan maneuvering kapal maka kapal akan mengalami variasi sudut belokan yang dapat mengubah arah gerak kapal. Pengaruh gelombang tersebut maka akan memberikan dampak yang signifikan pada performance kapal.

Perkembangan teknologi dalam bidang perkapalan dapat mendukung proses analisa memanfaatkan perkembangan teknologi adalah perhitungan numerik dengan menggunakan apa yang disebut Computational Fluid Dynamics (CFD) yang memanfaatkan perkembangan teknologi berkecepatan tinggi [2]. Teknik CFD memungkinkan penyelidikan sebuah model dengan ketelitian yang sangat tinggi tetapi dengan konsekuensi memerlukan kapasitas memori komputer yang tinggi pula.

Dengan efisiensi konfigurasi lambung katamaran flat side inside dan lambung kapal katamaran simetris, maka perlu dianalisa mengenai hubungan pengaruh sideforce dengan variasi konfigurasi lambung kapal. Pengaruh sideforce akan memberikan perbedaan yang berbeda pada jarak radius maneuvering kapal yang memiliki konfigurasi lambung yang berbeda. Aliran fluida yang dibedakan menjadi aliran laminar dan aliran turbulen menjadi dasar utama maneuvering kapal serta performa kapal.

\section{TINJAUAN PUSTAKA}

\section{A. Kapal Katamaran}

Kapal katamaran memiliki banyak keuntungan dibandingkan dengan kapal monohull. Kapal katamaran memiliki luasan geladak yang lebih luas dan tingkat stabiltas melintang yang lebih baik dibandingkan dengan kapal monohull), kapal katamaran memberikan kebebasan pada aspek desain bentuk lambung kapal dan dimensi dari demihull untuk meningkatkan stabilitas transversal. Aspek desain yang fleksible ini membuat katamaran dapat didesain relative asimetris terhadap centerplane [1]. Secara umum terdapat tiga macam bentuk dasar dari lambung katamaran yang dapat diadopsi, yaitu: 
- Katamaran Simetris, katamaran simetris merupakan desain bentuk lambung katamaran yang diadaptasi langsung dari variasi bentuk lambung konvensional.

- Katamaran Asimetris, katamaran asimetris merupakan bentuk katamaran yang dikembangkan dengan menggeser volume displacement asimetris didalam atau diluar centerline demihull untuk mengurangi efek interferensi yang merugikan antar demihull.

- Katamaran Asimetris Penuh, katamaran asimetris penuh merupakan bentuk lambung yang diperoleh dengan menggeser semua volume displacemen dari simetris hull ke salah satu sisi centerline seperti membagi monohull menjadi dua bagian centerline. Bentuk ini juga disebut separuh monohull atau lambung sobek.

\section{B. Sideforce}

Sideforce atau gaya samping (gaya sejajar dengan sumbu-y) yang dihasilkan dapat diprediksi dengan menggunakan pendekatan Lighthill, yang menunjukkan bahwa distribusi kekuatan sisi dapat dinyatakan dalam bentuk "koefisien massa tambahan" [3]. Selain sideforce gaya angkat pada kapal dapat mempengaruhi performa maneuvering kapal sehingga kapal memiliki performa yang berpengaruh terhadap olah geraknya, gaya angkat inilah yang disebut dengan lift. Dimana gaya angkat merupakan gaya yang tegak lurus terhadap arah pergerakan kapal. Dengan demikian gaya hambat berlawanan dengan arah pergerakan benda, dan dalam sebuah kendaraan yang digerakkan mesin di atasi dengan gaya dorong atau drag.

Penelitian mengenai sideforce difokuskan terutama untuk menghitung induced drag dan gaya samping (sideforce) pada katamaran. Hasil penelitian menyimpulkan bahwa induced drag yang ditimbulkan katamaran dapat diabaikan namun sideforce yang dihasilkan cukup signifikan. Sideforce yang dihasilkan menurun dengan cepat ketika adanya peningkatan jarak antara lambung. Koeffisien sideforce terdiri dari yaw angle pada variasi kecepatan kapal katamaran serta WSA (wet surface area) pada single demihull [4]. Dapat dirumuskan sebagai berikut:

sideforce coeficient $(C I)=\frac{\text { side force }}{1 / 2 \mu W S A U^{2}}$

sideforce coeficient $(C I)=$

Drag at incident-Drag at zero incident $1 / 2 \mu W S A U^{2}$

\section{Computational Fluid Dynamics (CFD)}

CFD adalah metode perhitungan, memprediksi dan pendekatan aliran fluida secara numerik dengan bantuan komputer berkecepatan tinggi. CFD juga didefinisikan sebagai suatu proses analisa terhadap suatu sistem tertentu yang melibatkan masalah perpindahan panas, aliran fluida, distribusi kecepatan dan fenomena terkait dengan dinamika fluida dimana proses perhitungan dan analisa dilakukan dengan menggunakan komputer [2].

Program CFD terdiri dari tiga tahap yaitu : Preprocessor, Processor, dan Post-processor. PreProcessor, merupakan tahap dimana data dimasukan mulai dari pendefinisian domain serta pendefinisian kondisi batas atau boundary condition. Pada tahap ini juga sebuah obyek atau benda dan ruangnya yang melingkupinya akan dianalisis dibagi-bagi dengan jumlah grid tertentu. Hal ini sering disebut dengan meshing. Processor, merupakan tahap dilakukannya proses perhitungan data-data input degan persamaan yang terlibat secara iterative. Pada tahap ini perhitungan dilakukan hingga menuju error terkecil atau hingga mencapai nilai yang konvergen. Perhitungan dilakukan secara menyeluruh terhadap volume kontrol dengan proses integrasi persamaan diskrit. Post-processor, merupakan tahap dimana hasil perhitunga diinterprestasikan kedalam gambar, grafik, bahkan animasi dengan pola-pola warna tertentu.

Pada proses pemodelan kapal katamaran, analisa CFD akan dilakukan dengan bantuan modeller. Modeller CFD digunakan pada tahap pembuatan geometri lambung tahap meshing baik pada model maupun pada fluida.. Analisa CFD yang akan dilakukan pada pemodelan lambung katamaran ini adalah pemodelan aliran dan perhitungan besarnya sideforce pada lambung tersebut serta visualisasi aliran fluida.

\section{Maneuvering}

Kemampuan manuver sebuah kapal dapat didefiniskan sebagai kemampuan kapal untuk mempertahankan atau mengubah posisi dari gerakan kapal di bawah kontrol. Seiring perkembangan zaman kini kemampuan manuver sebuah kapal dapat diprediksi dengan program/software. Dalam manuver kapal ada beberapa hal yang harus diperhatikan [5], yaitu :

1. Inherent dynamic stability, atau yang juga di sebut dengan straight line stability. Suatu kapal terkadang dapat bergerak dinamis ketika berjalan lurus, dengan gangguan-gangguan kecil kapal akan berada pada kodisi stright course yang lain, hal itu terjadi secara otomatis dan tidak dapat dikendalikan.

2. Course keeping ability, atau yang juga disebut dengan directional stability. Course keeping ability adalah kempauan kapal untuk memeprtahankan posisi kapal tetap berada pada original course direction.

3. Initial turning/course changing ability, adalah kemampuan kapal untuk mengubah gerakananya sebagi akibat dari kendali yang diberikan pada kapal.

4. Yaw checking ability, adalah kemampuan mengendalikan kapal akibat gerakan dari rudder yang dapat mengakibatkan kapal berbelok.

5. Turning ability, adalah kemempuan kapal berbelok karena pengeruh yang diberikan rudder yang berbelok.

6. Stopping ability adalah kemempauan menghentikan kapal dengan menghentikan (inertia stop) atau engine full astern (crash stop) mesin ketika kapal bergerak stabil dengan kecepatan penuh.

Dalam persamaan dasar dari gerakan manuver kapal persamaan berikut sehubungan dengan sumbu disepakati pada sebuah kapal, dijelaskan dengan persamaan Euler [6].

$$
\begin{aligned}
& \mathrm{mů}_{\mathrm{u}}-\operatorname{mvr}=X(\mathrm{u}, \mathrm{v}, \mathrm{r}, \delta, \stackrel{\mathrm{u}}{\mathrm{r}}, \dot{\mathrm{r}}) \\
& \mathrm{mu}+\operatorname{mur}=\mathrm{Y}(\mathrm{u}, \mathrm{v}, \mathrm{r}, \delta, \stackrel{\circ}{\mathrm{u}}, \dot{\mathrm{r}}, \mathfrak{v}) \\
& \mathrm{I} \dot{\mathrm{r}}=\mathrm{N}(\mathrm{u}, \mathrm{v}, \mathrm{r}, \delta, \stackrel{\mathrm{u}}{\mathrm{r}} \dot{\mathrm{r}}, \mathfrak{v})
\end{aligned}
$$

Dimana,

m : massa kapal 
I : Momen inersia memperhatikan sumbu vertikal di pusat gravitasi kapal

$\mathrm{X}, \mathrm{Y}$ : Gaya-gaya hidrodinamika secara memanjang dan melintang yang bekerja pada kapal

$\mathrm{N} \quad$ : gaya atau momen hidrodinamika y ang bekerja pada kapal

$\mathrm{r} \quad$ : kecepatan angular dari belokan, yang memiliki hubungan, $\mathrm{r}=\Psi$

Dalam hubungan antara bagaimana pengaruh sideforce terhadap maneuvering. Total sideforce dalam hal maneuvering kapal [7], terdiri dari:

a. Kontribusi dari kemudi,

b. Sideforce karena baling-baling di aliran menyamping,

c. Lambung yang didapatkan karena kombinasi kemudi baling-baling.

\section{III. METODOLOGI PENELITIAN}

\section{A. Metode}

Dalam penyelesaian penelitian ini digunakan metode analisa, simulasi, dan perhitungan secara sistematis. Prosedur pengerjaan disusun dengan urutan sebagai berikut: berikut

Prosedur pengerjaan disusun dengan urutan sebagai

\section{Studi Literatur}

Studi literatur yang dilakukan adalah yang berkaitan dengan pemahaman teori dan konsep dari perhitungan mengenai besarnya nilai sideforce yang dihasilkan dari adanya perbedaan konfigurasi lambung dari kapal katamaran. Kemudian dilanjutkan untuk menganalisa mengenai pengaruh yang dihasilkan dari besarnya sideforce dari kapal katamaran terhadap maneuvering.

2. Pengumpuan Data

Data ukuran kapal diperoleh dari penelitian yang telah dilakukan sebelumnya [4].

3. Pemodelan, Simulasi CFD

Dalam pengerjaannya penelitan ini menggunkan software, antara lain:

a. Menggunkan software pemodelan kapal dalam proses desain model kapal katamaran simetris dan asimetris (flat side inside).

b. Menggunakan modeller CFD dalam proses meshing dan penentuan boundary layer atau kondisi batas yang akan digunkan dalam proses running.

c. Menggunakan CFD dalam proses running dan menentukan nilai sideforce dari kapal katamaran simetris dan katamaran asimetris (flat side inside).

4. Validasi

Hasil simulasi dikatakan valid apabila selisih antara grid independence kurang dari $2 \%$.

5. Analisa Data dan Penyelesaian

Analisis data hasil dari simulasi model numerik dan perhitungan secara teori. Pada simulasi numerik adalah nilai besarnya sideforce, selanjutnya nilai sideforce dilakukan analisa pengaruh sideforce terhadap maneuvering (Gambar 1).

\section{B. Proses Pengerjaan}

Langkah awal dalam penelitian ini adalah menentukan ukuran utama kapal dan displacemen kapal. Dengan adanya perbedaan konfigurasi lambung katamaran makan membuat dua model kapal katamaran dengan software pemodelan kapal. Model yang dibuat adalah katamaran flat side inside dan katamaran simetris. Selanjutnya dari software pemodelan kapal, model di import pada modeller CFD, dimaksudkan agar model yang telah dibuat dapat dikenali oleh CFD.



Gambar 1. Bagan alir penelitian.

Kemudian pemasukan kondisi batas berdasarkan data eksperimen. Dalam simulasi CFD terdapat 3 tahapan yaitu Pre-Processor, Solver atau processor, dan Post-Processor [8]. Hasil dari running program CFD adalah berupa besar sideforce. Nilai sideforce yang diperoleh dalam simulasi dilakukan perhitungan yang diharapkan akan memperoleh nilai dari sideforce coefficient kapal pada setiap sudut kemiringan yang sudah ditentukan.

\section{PEMBUATAN MODEL DAN SIMULASI CFD}

\section{A. Pembuatan Model Uji Numerik}

Perancangan dimensi kapal mengacu pada penelitian yang sudah dilakukan [4] yang meneliti mengenai sideforce coefficient pada kapal katamaran simetris. Dari penelitian 
yang sudah dilakukan tersebut maka diperoleh data rasio dimensi sebagai berikut:

Tabel 1.

Tabel Rasio Dimensi

\begin{tabular}{ll}
\hline \hline $\mathrm{L} / \mathrm{B}$ & 11.0 \\
\hline $\mathrm{B} / \mathrm{T}$ & 2.0 \\
$\mathrm{~L}$ & $1.6 \mathrm{~m}$ \\
\hline \hline
\end{tabular}

Pembuatan model dibagi menjadi dua subyek besar, yaitu kapal katamaran Simetris dan kapal katamaran Asimetris Flat side inside. Dari dua subyek besar tersebut akan divariasikan dengan adanya perbedaan S/L pada kapal katamaran Simetris dan kapal katamaran Asimetris Flat side inside. Variasi S/L yang dilakukan adalah 0.2, 0.3, dan 0.4.


Gambar 2. Model kapal katamaran Simetris,
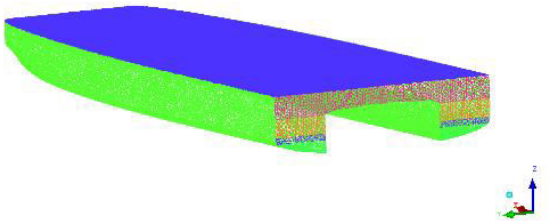

Gambar 3. Model kapal katamaran Asimetris flat side inside

Pada Gambar 4 ditunjukkan adanya sudut yang dibentuk dari heading sea (arah fluida) dengan centerline kapal sehingga membentuk sudut $\alpha$. Dimana sudut kemiringan $(\alpha)$ yang diatur adalah $2^{\circ}, 4^{\circ}, 6^{\circ}, 8^{\circ}, 10^{\circ}, 12^{\circ}, 14^{\circ}$ terhadap sumbu $\mathrm{Z}$ dan arah fluida pada simulasi berlawanan dengan arah gerakan kapal, dimana arah fluida adalah ke arah sumbu $\mathrm{x}$ negatif.

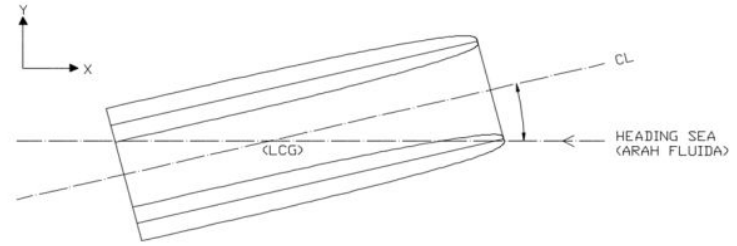

Gambar 4. Sudut Kemiringan Kapal Pada Simulasi CFD

\section{B. Simulasi $C F D$}

Pada simulasi CFD terdiri dari tiga tahap yaitu : Preprocessor, Processor, dan Post-processor. Pada tahap preprocessor perlu melakukan mendefinisikan domain dan boundary dari part-part yang telah dibuat di modeller CFD.

Namun pada simulasi free surface, model uji berada pada 2 fluida, yaitu fluida air dan udara. Sehingga perlu dilakukan pengaturan untuk dapat membagi domain menjadi 2 fluida. Kemudian tahap solver, tahap solver adalah tahap dimana proses running dimulai setelah proses pendefinisian domain dan boundary pada semua bagian yang telah dibuat pada modeller CFD serta solver control pada CFD telah dilakukan pengaturan. Pada proses running ini menampilkan grafik dimana sumbu $\mathrm{x}$ adalah acumulated time step (banyaknya jumlah (iterasi) dan sumbu y menunjukkan variable value (nilai konvergensi) dengan nilai 1 sampai sesuai dengan solver control pada tahap pre-processor. Konvergensi merupakan pengaturan persamaan solver control yang bertujuan meminimalisir error pada hasil simulasi. Proses iterasi akan berhenti sampai dengan variable value. Yang terakhir adalah tahap post-processor pada tahap ini mendapatkan hasil-hasil dari proses iterasi yang telah dilakukan.

\section{HASIL DAN PEMBAHASAN}

\section{A. Simulasi Free Surface}

\section{Kapal Katamaran Simetris}

Pada simulasi free surface diperoleh perbandingan nilai CSF untuk variasi sudut kemiringan pada kapal katamaran simetris. Untuk jarak antar lambung secara melintang atau yang disebut $\mathrm{S} / \mathrm{L}(\mathrm{S} / \mathrm{L}=0.2, \mathrm{~S} / \mathrm{L}=0.3$ dan $\mathrm{S} / \mathrm{L}=0.4)$ serta sudut kemiringan $\left(2^{\circ}, 4^{\circ}, 6^{\circ}, 8^{\circ}, 10^{\circ}, 12^{\circ}, 14^{\circ}\right)$. Selain diperoleh nilai dari sideforce coefficient (CSF) juga di peroleh

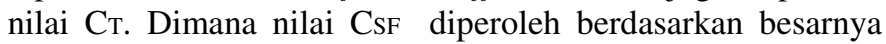
nilai force pada sumbu y, atau sumbu yang sejajar dengan arah melintang kapal. Sedangkan nilai $\mathrm{C}_{\mathrm{T}}$ diperoleh berdasarkan nilai besarnya force berdasarkan sumbu $\mathrm{x}$, atau sumbu yang sejajar dengan arah memanjang kapal.

Pada Tabel 2 dan Tabel 3 ditunjukkan bahwah nilai CsF dan Nilai $\mathrm{C}_{\mathrm{T}}$ pada kapal katamaran simetris semakin bertambah berbanding lurus dengan semakin bertambahnya sudut kemiringan dari kapal. Hal tersebut menujukkan bahwa pada sudut kemiringan di atas $8^{\circ}, 10^{\circ}, 12^{\circ}, 14^{\circ}$ nilai $\mathrm{F}(\mathrm{x})$ atau force pada sumbu $\mathrm{x}$ lebih kecil dibandingkan nilai $\mathrm{F}(\mathrm{y})$ atau force pada sumbu y. Hal tersebut terjadi pada variasi $\mathrm{S} / \mathrm{L}$ $=0.2, \mathrm{~S} / \mathrm{L}=0.3$, dan $\mathrm{S} / \mathrm{L}=0.4$.

Tabel 2.

Nilai CSF pada simulasi free surface kapal katamaran simetris

\begin{tabular}{|c|r|r|r|r|r|r|}
\hline \multirow{2}{*}{$\begin{array}{c}\text { SUDUT } \\
\text { KEMIRINGAN }\end{array}$} & \multicolumn{2}{|c|}{$\mathrm{S} / \mathrm{L}=0.2$} & \multicolumn{2}{c|}{$\mathrm{S} / \mathrm{L}=0.3$} & \multicolumn{2}{c|}{$\mathrm{S} / \mathrm{L}=0.4$} \\
\cline { 2 - 7 } & $\begin{array}{c}\text { SIDEFORCE } \\
(\mathrm{N})\end{array}$ & $\begin{array}{c}C_{S F} \\
\left(\times 10^{-2}\right)\end{array}$ & $\begin{array}{c}\text { SIDEFORCE } \\
(\mathrm{N})\end{array}$ & $\begin{array}{c}C_{S F} \\
\left(\mathrm{x} 10^{-2}\right)\end{array}$ & $\begin{array}{c}\text { SIDEFORCE } \\
(\mathrm{N})\end{array}$ & $\begin{array}{c}C_{S F} \\
\left(\mathrm{x} 10^{-2}\right)\end{array}$ \\
\hline 2 & 525.400 & 0.792 & 486.135 & 0.694 & 378.905 & 0.541 \\
\hline 4 & 960.240 & 1.447 & 811.505 & 1.159 & 744.001 & 1.062 \\
\hline 6 & 1341.150 & 2.021 & 1182.820 & 1.689 & 1045.020 & 1.492 \\
\hline 8 & 1844.160 & 2.779 & 1654.490 & 2.362 & 1552.105 & 2.216 \\
\hline 10 & 2651.770 & 3.995 & 2285.760 & 3.264 & 2088.390 & 2.982 \\
\hline 12 & 3005.341 & 4.528 & 2798.300 & 3.996 & 2509.600 & 3.584 \\
\hline 14 & 3488.240 & 5.256 & 3245.889 & 4.635 & 3045.580 & 4.349 \\
\hline
\end{tabular}

Tabel 3.

Nilai CT pada simulasi free surface pada kapal katamaran simetris 


\begin{tabular}{|c|r|r|r|r|r|r|}
\hline \multirow{2}{*}{$\begin{array}{c}\text { SUDUT } \\
\text { KEMIRINGAN }\end{array}$} & \multicolumn{2}{|c|}{$\mathrm{S} / \mathrm{L}=0.2$} & \multicolumn{2}{c|}{$\mathrm{S} / \mathrm{L}=0.3$} & \multicolumn{2}{c|}{$\mathrm{S} / \mathrm{L}=0.4$} \\
\cline { 2 - 7 } & $\begin{array}{c}\text { DRAGFORCE } \\
(\mathrm{N})\end{array}$ & $\begin{array}{c}C_{T} \\
\left(\mathrm{x} 10^{-2}\right)\end{array}$ & $\begin{array}{c}\text { DRAGFORCE } \\
(\mathrm{N})\end{array}$ & $\begin{array}{c}C_{T} \\
\left(\mathrm{x} 10^{-2}\right)\end{array}$ & $\begin{array}{c}\text { DRAGFORCE } \\
(\mathrm{N})\end{array}$ & $\begin{array}{c}C_{T} \\
\left(\mathrm{x} 10^{-2}\right)\end{array}$ \\
\hline 2 & 1506.970 & 2.2706 & 1112.507 & 1.5886 & 1094.366 & 1.5627 \\
\hline 4 & 1686.570 & 2.5412 & 1155.260 & 1.6496 & 1133.070 & 1.6179 \\
\hline 6 & 1739.110 & 2.6204 & 1252.980 & 1.7892 & 1190.680 & 1.7002 \\
\hline 8 & 1789.020 & 2.6956 & 1453.840 & 2.0760 & 1255.330 & 1.7925 \\
\hline 10 & 1864.400 & 2.8091 & 1619.790 & 2.3129 & 1351.130 & 1.9293 \\
\hline 12 & 1956.350 & 2.9477 & 1791.080 & 2.5575 & 1565.310 & 2.2351 \\
\hline 14 & 2068.980 & 3.1174 & 2002.410 & 2.8593 & 1917.640 & 2.7383 \\
\hline
\end{tabular}

2. Kapal Katamaran Asimetris (Flat side inside).

Dengan adanya variasi konfigurasi lambung pada kapal katamaran, maka simulasi free surface dilakukan juga pada kapal katamaran dengan variasi konfigurasi lambung asimetris flat side inside. Untuk jarak antar lambung secara melintang atau yang disebut $\mathrm{S} / \mathrm{L}(\mathrm{S} / \mathrm{L}=0.2, \mathrm{~S} / \mathrm{L}=0.3$ dan $\mathrm{S} / \mathrm{L}=0.4)$ serta sudut kemiringan $\left(2^{\circ}, 4^{o}, 6^{\circ}, 8^{\circ}, 10^{\circ}, 12^{\circ}, 14^{\circ}\right)$. Selain diperoleh nilai dari sideforce coefficient (CSF) juga di peroleh nilai $\mathrm{CT}$.

Pada Tabel 4 dan Tabel 5 ditunjukkan bahwa nilai CsF dan Nilai $\mathrm{C}_{\mathrm{T}}$ pada kapal katamaran asimetris flat side inside semakin bertambah berbanding lurus dengan semakin bertambahnya sudut kemiringan dari kapal. Hal tersebut menujukkan bahwa pada sudut kemiringan di atas $8^{\circ}, 10^{\circ}, 12^{\circ}, 14^{\circ}$ nilai $\mathrm{F}(\mathrm{x})$ atau force pada sumbu $\mathrm{x}$ lebih kecil dibandingkan nilai $\mathrm{F}(\mathrm{y})$ atau force pada sumbu y. Hal tersebut terjadi pada variasi $\mathrm{S} / \mathrm{L}=0.2, \mathrm{~S} / \mathrm{L}=0.3$, dan $\mathrm{S} / \mathrm{L}=$ 0.4 .

Tabel 4.

Nilai CSF pada simulasi free surface kapal katamaran asimetris flat side inside

\begin{tabular}{|c|r|r|r|r|r|r|}
\hline \multirow{2}{*}{$\begin{array}{c}\text { SUDUT } \\
\text { KEMIRINGAN }\end{array}$} & \multicolumn{2}{|c|}{$\mathrm{S} / \mathrm{L}=0.2$} & \multicolumn{2}{|c|}{$\mathrm{S} / \mathrm{L}=0.3$} & \multicolumn{2}{|c|}{$\mathrm{S} / \mathrm{L}=0.4$} \\
\cline { 2 - 7 } & $\begin{array}{c}\text { SIDEFORCE } \\
(\mathrm{N})\end{array}$ & $\begin{array}{c}C_{S F} \\
\left(\mathrm{x} 10^{-2}\right)\end{array}$ & $\begin{array}{c}\text { SIDEFORCE } \\
(\mathrm{N})\end{array}$ & $\begin{array}{c}C_{S F} \\
\left(\mathrm{x} 10^{-2}\right)\end{array}$ & $\begin{array}{c}\text { SIDEFORCE } \\
(\mathbb{N})\end{array}$ & $\begin{array}{c}C_{S F} \\
\left(\mathrm{x} 10^{-2}\right)\end{array}$ \\
\hline 2 & 503.616 & 0.759 & 486.889 & 0.695 & 470.160 & 0.671 \\
\hline 4 & 1042.050 & 1.570 & 844.884 & 1.206 & 717.637 & 1.025 \\
\hline 6 & 1585.653 & 2.389 & 1412.620 & 2.017 & 1261.250 & 1.801 \\
\hline 8 & 2043.151 & 3.078 & 1956.390 & 2.794 & 1749.043 & 2.498 \\
\hline 10 & 2396.212 & 3.610 & 2264.976 & 3.234 & 2143.571 & 3.061 \\
\hline 12 & 2776.190 & 4.183 & 2721.325 & 3.886 & 2573.500 & 3.675 \\
\hline 14 & 3495.102 & 5.266 & 3256.709 & 4.650 & 3085.199 & 4.405 \\
\hline
\end{tabular}

Tabel 5.

Nilai CT pada simulasi free surface pada kapal katamaran asimetris flat side inside

\begin{tabular}{|c|r|r|r|r|r|r|}
\hline \multirow{2}{*}{$\begin{array}{c}\text { SUDUT } \\
\text { KEMIRINGAN }\end{array}$} & \multicolumn{2}{|c|}{ S/L $=0.2$} & \multicolumn{2}{|c|}{ S/L $=0.3$} & \multicolumn{2}{|c|}{$\mathrm{S} / \mathrm{L}=0.4$} \\
\cline { 2 - 7 } & $\begin{array}{c}\text { DRAGFORCE } \\
(\mathrm{N})\end{array}$ & $\begin{array}{c}C_{T} \\
\left(\mathrm{x} 10^{-2}\right)\end{array}$ & $\begin{array}{c}\text { DRAGFORCE } \\
(\mathrm{N})\end{array}$ & $\begin{array}{c}C_{T} \\
\left(\mathrm{x} 10^{-2}\right)\end{array}$ & $\begin{array}{c}\text { DRAGFORCE } \\
(\mathrm{N})\end{array}$ & $\begin{array}{c}C_{T} \\
\left(\mathrm{x} 10^{-2}\right)\end{array}$ \\
\hline 2 & 1711.870 & 2.579 & 1637.854 & 2.339 & 1422.100 & 2.031 \\
\hline 4 & 1794.753 & 2.704 & 1700.334 & 2.428 & 1481.730 & 2.116 \\
\hline 6 & 1828.926 & 2.756 & 1774.063 & 2.533 & 1588.719 & 2.269 \\
\hline 8 & 1903.100 & 2.867 & 1875.800 & 2.679 & 1704.400 & 2.434 \\
\hline 10 & 2172.420 & 3.273 & 2085.900 & 2.979 & 1982.660 & 2.831 \\
\hline 12 & 2300.790 & 3.467 & 2265.819 & 3.235 & 2114.600 & 3.019 \\
\hline 14 & 2620.440 & 3.948 & 2408.700 & 3.439 & 2129.762 & 3.041 \\
\hline
\end{tabular}

3. Perbandingan simulasi free surface katamaran asimetris flat side inside dan katamaran simetris

Simulasi free surface yang sudah dilakukan pada kedua konfigurasi lambung, yaitu katamaran asimetris flat side inside dan katamaran simetris, maka diperoleh data perbandingan nilai sideforce coefficient dari kedua perbedaan konfigurasi lambung berdasarkan konfigurasi lambung yang berbeda, namun dengan variasi $\mathrm{S} / \mathrm{L}$ yang sama dan sudut kemiringan kapal yang sama.

Pada Gambar 5 dan Gambar 6 ditunjukkan bahwa dengan nilai S/L yang semakin besar maka nilai CSF semakin berkurang, yang berarti pada kapal katamaran dengan nilai S/L $=0.4$ memiliki nilai CsF yang paling kecil dibandingakan dengan kapal katmaran dengan $\mathrm{S} / \mathrm{L}=0.2$ dan $\mathrm{S} / \mathrm{L}=0.3$. Dimana, jarak antara lambung secara melintang (S/L) berpengaruh terhadap nilai force. Force akan semakin bertambah apabila terjadi penurunan nilai jarak antara lambung secara melintang (S/L) [9]. Disamping itu dengan adanya pengaruh kemiringan sudut, pada kapal katamaran simetris maupun kapal katamaran asimetris flat side inside nilai CSF semakin bertambah seiring dengan bertambahnya sudut kemiringan. Pada konfigurasi lambung katamaran simetris dan katamaran asimetris flatside inside, kapal katamaran asimetris flat side inside memiliki nilai CSF yang lebih besar dibandingkan kapal katamaran simetris.



Gambar 5. Perbandingan CSF kapal katamaran simetris

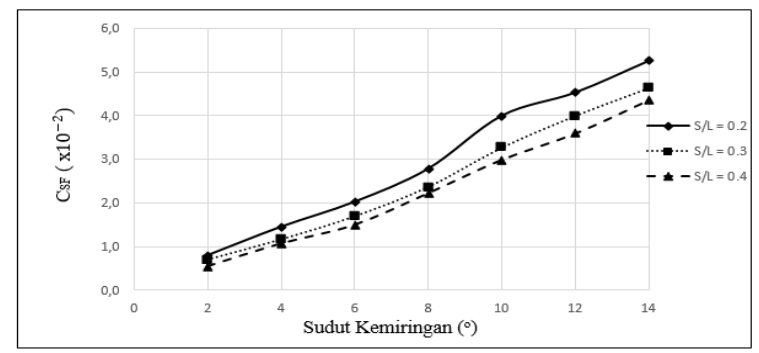

Gambar 6. Perbandingan CSF kapal katamaran asimetris flat side inside.

\section{B. Hubungan Sideforce dan Maneuvering}

Adanya hubungan antara gaya atau momen hidrodinamika yang bekerja pada kapal dengan kecepatan angular dari belokan kapal saat melakukan manuver ditunjukkan pada persamaan (3), dimana kecepatan angular dari belokan kapal saat melakukan manuver dikalikan dengan momen inersia berdasarkan sumbu vertikal di pusat gravitasi kapal, sehingga dari perkalian tersebut ditunjukkan hubungan antara kecepatan angular dari belokan kapal saat melakukan manuver berbanding lurus dengan gaya atau momen hidrodinamika yang bekerja pada kapal. Gaya yang dimaksud adalah gaya yang terdiri dari gaya atau momen yang bekerja pada lambung, baling-baling dan kemudi, yang dipengeruhi oleh kondisi aliran serta kondisi kerja seperti baling-baling dan perubahan pada sudut kemiringan kemudi [6]. Gaya yang bekerja pada lambung ini salah satunya adalah sideforce. 
Nilai sideforce pada penelitian ini ditunjukkan pada Tabel 2 dan Tabel 4, nilai sideforce semakin besar berbanding lurus dengan semakin besarnya sudut kemiringan. Sehingga dalam hubungan sideforce dalam hal maneuvering kapal semakin besar sudut kemiringan kapal maka semakin besar nilai sideforce dan semakin besar kecepatan angular dari belokan kapal saat melakukan manuver.

\section{KESIMPULAN}

Setelah didapatkan hasil penelitian, maka kesimpulan yang diperoleh sebagai berikut:

1. Berdasarkan data yang didapatkan pada kapal katamaran simetris nilai sideforce dan CsF terbesar pada $\mathrm{S} / \mathrm{L}=0.2$ dengan sudut kemiringan $14^{\circ}$, yaitu sideforce $=3488.240$ $\mathrm{N}$ dan $\mathrm{CsF}=5.256 \times 10-2$. Sedangkan nilai sideforce dan CSF terkecil pada $\mathrm{S} / \mathrm{L}=0.4$ dengan sudut kemiringan $2^{\circ}$, yaitu sebesar sideforce $=378.905 \mathrm{~N}$ dan $\mathrm{CsF}=0.541 \mathrm{x} 10$ 2. Pada kapal katamaran asimetris flat side inside nilai sideforce dan CSF terbesar pada $\mathrm{S} / \mathrm{L}=0.2$ dengan sudut kemiringan $14^{\circ}$, yaitu sideforce $=3495.102 \mathrm{~N}$ dan CSF $=$ $5.266 \times 10-2$. Sedangkan nilai sideforce dan CsF terkecil pada $\mathrm{S} / \mathrm{L}=0.4$ dengan sudut kemiringan $2^{\circ}$, yaitu sebesar sideforce $=470.160 \mathrm{~N}$ dan $\mathrm{CsF}=0.671 \times 10-2$.

2. Perbedaan konfigurasi lambung pada kapal katamaran memiliki sideforce dan nilai CSF yang berbeda sesuai dengan konfigurasi lambung, yaitu kapal katamaran simetris dan kapal katamaran asimetris flat side inside. Kapal katamaran asimetris memiliki nilai sideforce yang lebih besar dibandingkan dengan kapal katamaran simetris.

3. Pada kapal katamaran simetris dan asimetris flat side inside pada sudut kemiringan $2^{\circ}, 4^{\circ}, 6^{\circ}$ nilai CsF lebih

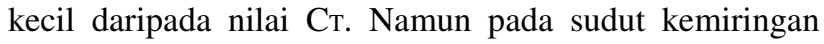

$8^{\circ}, 10^{\circ}, 12^{\circ}, 14^{\circ}$ CSF memiliki nilai yang lebih besar daripada nilai $\mathrm{C}$.

4. Gaya yang bekerja pada badan kapal dapat memberikan pengaruh terhadap maneuvering kapal, salah satunya adalah gaya yang berasal dari bagian sisi kapal di sumbu Y (sumbu yang tegak lurus dengan arah laju kapal). Sehingga dalam hubungan sideforce dalam hal maneuvering kapal semakin besar sudut kemiringan kapal maka semakin besar nilai sideforce dan semakin besar kecepatan angular dari belokan kapal saat melakukan manuver.

\section{DAFTAR PUSTAKA}

[1] M. Insel and A. F. Molland, "An Investigation into The Resistance Component of High Speed Displacement Catamarans," United Kingdom, 1990.

[2] H. K. Versteeg and W. Malalasekera, "An introduction to computional Fluid Dynamics," England, 2007.

[3] W. S. Hunter and P. N. Joubert, "Sideforces on a ship's hull," USA, 1988.

[4] P. Couser, "Experimental Measurement Of Sideforces And Induced Drag On Catamaran Demihull," Int. Shipbuild. Prog., vol. 45, no. 433, pp. 225-235, 1998.

[5] V. Bertram, Practical Ship Hydrodunamics. United Kingdom: Butterworth - Heinemann Ltd, 2002.

[6] T. Fuwa and K. Tatsuo, "Theory, Analysis, And Design Methodology For Ship Manoeuverability," Japan, 1973.

[7] A. Molland and S. Turnock, Marine Rudder and Control Surfaces. United Kingdom: Butterworth - Heinemann Ltd, 2007.

[8] I. K. A. P. Utama, "Investigation of the Viscous Resistance Component of Catamaran Forms," University of Southampton, 1999.

[9] R. M. Hutauruk and Latumeirissa, "Kajian Interferensi Aliran pada Model Trimaran untuk Mengungkapkan Hambatan Viskos dengan Menggunakan Uji Terowongan Angin," J. Teknol., vol. 10, no. 1, 2013. 